\section{Seedling Emergence of Tall Fescue and Kentucky Bluegrass, as Affected by Two Seed Coating Techniques}

\author{
M.D. Richardson ${ }^{1,3}$ and K.W. Hignight ${ }^{2}$
}

Additional Index Words. polymer, turfgrass, Zeba, Penkoted

SUMMARY. Seed coating has been effectively used in the agricultural and horticultural industries for over 100 years. Recently, several turfgrass seed companies have been applying seed coating technologies to commercial seed lines, but there have been limited studies that have demonstrated a positive benefit of seed coating to turfgrass seed. The objective of this study was to determine the effects of two commercially available seed coating technologies, including a fungicide/biostimulant coating and a starch-based polymer coating, on tall fescue (Festuca arundinaceae) and kentucky bluegrass (Poa pratensis) in three soil types. Coated seeds were obtained from a retail outlet. Non-coated seed samples were developed by removing the coating from the seed just before planting. Neither coating technology had an effect on tall fescue speed of germination or total germination percentage in any of the soil types. Seed coating did have a positive effect on the speed of germination of kentucky bluegrass in a sandy loam soil, but did not improve the speed of germination or percentage emergence in the other soil types. These results support earlier findings that seed coating has minimal effects on establishment of turfgrass species. However, these coatings may provide benefits when attempting to establish turfgrasses in less than ideal conditions.

S eed coating technologies have been used in the agricultural and horticultural industries for several decades (Bishnoi and Wilhite, 2005; Otey, 1983; Woodhouse and Johnson, 1991). Seed coatings have been used to deter insects (Nault et al., 2006) and fungi (Salter and Smith, 1986), incorporate beneficial microbes (Rice et al., 2001), enhance seed handling characteristics, and improve germination and seedling establishment (PeltonenSainio et al., 2006; Scott and Hay, 1974). Although these technologies have been successful with specific crops such as vegetables and legumes, their success with forage or turfgrass seeds has been modest (Dowling, 1978; Hathcock et al., 1984a, 1984b).

Over the past 5 years, turfgrass seed companies have begun to coat many lawn grass seeds with seed coatings that are described as having a beneficial effect on germination and establishment. Earlier studies of seed coatings on grass seeds have shown minimal positive effects (Bruneau et al., 1989; Dowling, 1978; Hathcock et al., 1984a), especially when using starch-based polymers (Berdahl and

${ }^{1}$ Professor, Department of Horticulture, University of Arkansas, Fayetteville, AR 72701

${ }^{2}$ Director of Research, Nexgen Turf Research, LLC, Albany, OR 97321

${ }^{3}$ Corresponding author. E-mail: mricha@uark.edu.
Barker, 1980). Based on these earlier reports that indicated minimal effects of polymers or other seed coatings on turfgrass seed germination and establishment, it was hypothesized that current seed coating technologies are providing minimal benefits to turfgrass seed. The objective of this study was to determine the effect of two seed coating technologies on the establishment of two turfgrass species in three soil types.

\section{Materials and methods}

Two commercially available, coated seed sources were used for these studies, including Smart Seed (Pennington Seed, Madison, GA) and Turf Builder Grass Seed with Water Smart (Scotts, Marysville, $\mathrm{OH}$ ). Tall fescue and kentucky bluewere purchased at a retail outlet. Smart Seed contains a proprietary liquid coating material (Penkoted ${ }^{\circledR}$; Pennington Seed) containing a fungicide and a growth stimulant. Turf Builder grass samples of both seed sources seeds were coated with a starch-based polymer technology (Zeba seed coating $\left({ }^{\circledR}\right.$; Zeba, Beaverton, OR) that is designed to absorb and retain water around the seed.

For each seed lot, a non-coated seed treatment was developed by washing the coated seed under a stream of warm $\left(104^{\circ} \mathrm{F}\right)$ water for $\approx 5$ min, which effectively removed all the seed coating from the seeds (Fig. 1). The coated and non-coated seeds were planted immediately after washing into the test soils. It was also observed that the Zeba ${ }^{\circledR}$ coating was highly variable on the tall fescue and kentucky bluegrass seed lots (Fig. 1). As such, a third treatment was developed for the Turf Builder seed lots (Zeba ${ }^{\circledR}$ coated) and included a heavily coated seed lot and a partially coated seed lot. Heavily coated seeds only comprise $3 \%$ to $5 \%$ of the product in the bag but exhibit the greatest water absorbing capacity (K.W. Hignight, unpublished results). Sufficient seeds to conduct all experiments were separated by hand into heavily coated and partially coated seed treatments. A seed weight was determined for each seed treatment and was used to verify the difference in coating thickness of the partially and heavily coated Turf Builder seed lots (Table 1). Although the inert material (primarily seed coating) in retail packages of Turf Builder is typically around $50 \%$, the seed weight results suggest that Zeba ${ }^{\circledR}$ seed coating can increase seed weight by as much as 6-fold when heavily coated (Table 1).

All seed coating treatments for both turfgrass species were evaluated for emergence in three soil types including the following: 1) a Captina silt loam (fine-silty, siliceous, active, mesic Typic Fragiudults, with an average $\mathrm{pH}$ of 6.2 , and $45 \mathrm{lb} /$ acre phosphorous $(\mathrm{P})$ and $183 \mathrm{lb} /$ acre potassium $(\mathrm{K}) ; 2$ ) a commercial sandy loam soil mix (The Bark Place, Albany, OR) containing $51.3 \%$ sand, $38.2 \%$ silt, and $10.8 \%$ clay, with an average $\mathrm{pH}$ of 6.6 , and $22 \mathrm{lb} /$ acre P and $262 \mathrm{lb} /$ acre K; and 3) a Woodburn silt loam (fine-silty,

\begin{tabular}{llll}
\hline $\begin{array}{l}\text { Units } \\
\begin{array}{l}\text { To convert U.S. to SI, } \\
\text { multiply by }\end{array}\end{array}$ & U.S. unit & SI unit & $\begin{array}{l}\text { To convert SI to U.S., } \\
\text { multiply by }\end{array}$ \\
\hline 2.54 & inch $(\mathrm{es})$ & $\mathrm{cm}$ & 0.3937 \\
1.1209 & $\mathrm{lb} / \mathrm{acre}$ & $\mathrm{kg} \cdot h \mathrm{ha}^{-1}$ & 0.8922 \\
28.3495 & $\mathrm{OZ}$ & $\mathrm{g}$ & 0.0353 \\
$\left({ }^{\circ} \mathrm{F}-32\right) \div 1.8$ & ${ }^{\circ} \mathrm{F}$ & ${ }^{\circ} \mathrm{C}$ & $\left(1.8 \times{ }^{\circ} \mathrm{C}\right)+32$
\end{tabular}



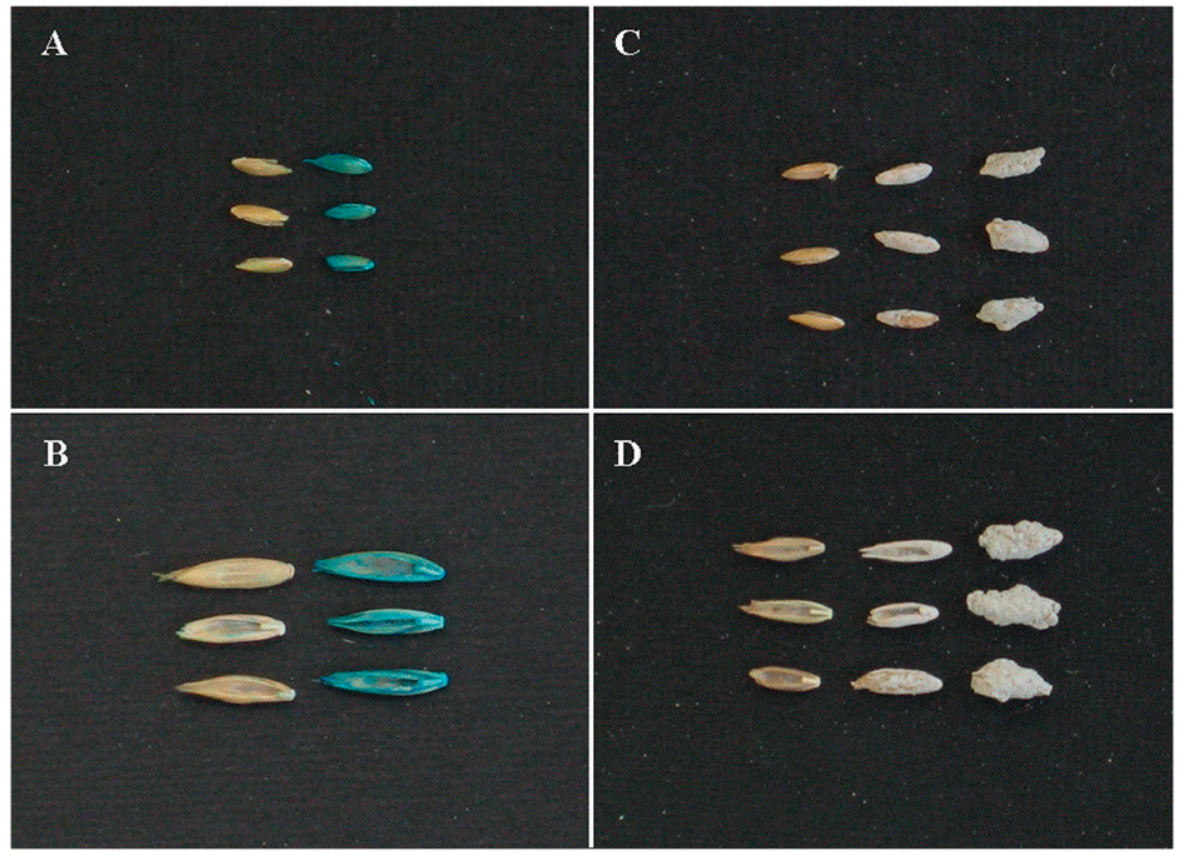

Fig. 1. Images of the various seed treatments tested in the study, including (A) Smart Seed kentucky bluegrass (Pennington Seed, Madison, GA), (B) Smart Seed tall fescue, (C) Turfbuilder kentucky bluegrass (Scotts, Marysville, $\mathrm{OH}$ ), and (D) Turfbuilder tall fescue. For all seed samples, the non-coated seed is on the left. For the Turfbuilder samples (C and D), the partial coated seed is in the middle and the heavily coated seed is on the right.

Table 1. Weight of seeds from each seed coating treatment and turfgrass species. Three separate tests, each containing four replicate, 25-seed samples, were conducted and then converted to 1000 -seed weight for analysis.

\begin{tabular}{llc}
\hline Turfgrass species & Seed coating treatment ${ }^{\mathrm{z}}$ & Seed wt $(\mathbf{g} / \mathbf{1 0 0 0} \text { seeds })^{\mathrm{y}}$ \\
\hline Kentucky bluegrass & Smart Seed - Penkoted ${ }^{\circledR}$ & 0.38 \\
& Smart Seed - no coating & 0.39 \\
& Turfbuilder - heavy Zeba ${ }^{\circledR}$ & 1.82 \\
& Turfbuilder - partial Zeba ${ }^{\circledR}$ & 0.70 \\
& Turfbuilder - no coating & 0.38 \\
& LSD $(0.05)^{\mathrm{x}}$ & 0.11 \\
Tall fescue & Smart Seed - Penkoted ${ }^{\circledR}$ & 2.46 \\
& Smart Seed - no coating & 2.24 \\
& Turfbuilder - heavy Zeba ${ }^{\circledR}$ & 7.50 \\
& Turfbuilder - partial Zeba ${ }^{\circledR}$ & 3.72 \\
& Turfbuilder - no coating & 2.36 \\
& LSD $(0.05)$ & 0.16 \\
\hline
\end{tabular}

${ }^{2}$ Penkoted ${ }^{\circledR}$ (Pennington Seed, Madison, GA), Zeba ${ }^{\circledR}$ (Zeba, Beaverton, OR).

${ }^{\mathrm{y}} \mathrm{l} \mathrm{g}=0.0353 \mathrm{oz}$.

${ }^{x}$ Least significant difference $(P=0.05)$ can be used to compare means within a turfgrass species.

mixed, superactive Aqultic Argixeroll) with an average $\mathrm{pH}$ of 6.5 , and $46 \mathrm{lb} /$ acre $\mathrm{P}$ and $302 \mathrm{lb} /$ acre K. No fertilizer was added to any of the soils before the study. Emergence experiments for the Captina silt loam soil were conducted in greenhouse facilities at the University of Arkansas, Fayetteville, while emergence tests for the commercial sandy loam and Woodburn silt loam treatments were conducted in greenhouse facilities at NexGen Turf
Research in Albany, OR. All soils were steam-sterilized (at $200{ }^{\circ} \mathrm{F}$ for $8 \mathrm{~h}$ ) before use to assure that no weed seed contaminants or pathogens were present. Identical seed lots were used for all soil treatments, but non-coated treatments were developed at the two locations just before conducting emergence studies, as previously described.

For each soil type and seed treatment, 25 seeds were planted in a greenhouse flat $(12 \times 12$ inches $)$ filled with
2.0 inches of the test soil. A planting device was used to make small impressions $(\approx 1 / 8$ inch deep) in the soil on a $5 \times 5$ grid (2-inch grids) and seeds were individually placed in the impression and lightly covered with similar soil. Each 25-seed flat was considered an experimental unit of that soil $\times$ seed treatment. Each soil $\times$ seed treatment was replicated four times and arranged along the greenhouse bench in a randomized complete block design. A mist irrigation system was used to maintain soil moisture that was ideal for germination and emergence throughout the experiment. For the commercial sandy loam and Woodburn silt loam treatments, water was withheld on days 3 and 5 after seeding due to sufficient soil moisture for germination to occur. For each experimental unit, the following data were collected: days after planting (DAP) when first emergence was observed and percentage of seeds emerged at the end of a 28 -d observation period. The effects of seed coating were determined using analysis of variance procedures of the randomized complete block design. Coating effects were analyzed separately for each soil type and turfgrass species.

\section{Results and discussion}

Neither of the coating technologies had an effect on tall fescue emergence date or percentage emergence in any of the soils (Table 2). Earlier investigations of seed coatings on tall fescue also demonstrated minimal effects (Dowling, 1978; Hathcock et al., 1984a) or variable responses to fertilizer coatings (Hathcock et al., 1984b).

Coating had a significant effect on days to first emergence and percentage of emergence for kentucky bluegrass in all three soils, but the response was not consistent between the three soils (Table 2). In the Captina silt loam soil, seed coating had a significant effect on date of first germination, but the only treatment mean that was significantly different from the other treatments was a delayed germination in the partially coated Turf Builder seed (Table $2)$. In the sandy loam soil, the Zeba ${ }^{\circledR}$ coated and Penkoted ${ }^{\circledR}$ kentucky bluegrass seeds had faster germination than their respective, non-coated controls (Table 2). Because this soil had the highest sand content and the least water- and nutrient-holding capacity, it appears that seed coating might have 
Table 2. Average days after planting (DAP) for emergence and average percentage emergence for five different seed coating treatments and two turfgrass species.

\begin{tabular}{|c|c|c|c|c|c|c|c|}
\hline \multirow{3}{*}{$\begin{array}{l}\text { Turfgrass } \\
\text { species }\end{array}$} & \multirow{3}{*}{$\begin{array}{l}\text { Seed coating } \\
\text { treatment }\end{array}$} & \multicolumn{2}{|c|}{ Captina silt loam } & \multicolumn{2}{|c|}{ Processed sandy loam } & \multicolumn{2}{|c|}{ Woodburn silt loam } \\
\hline & & $\begin{array}{c}\text { First } \\
\text { emergence }\end{array}$ & $\begin{array}{c}\text { Avg } \\
\text { emergence }\end{array}$ & $\begin{array}{c}\text { First } \\
\text { emergence }\end{array}$ & $\begin{array}{c}\text { Avg } \\
\text { emergence }\end{array}$ & $\begin{array}{c}\text { First } \\
\text { emergence }\end{array}$ & $\begin{array}{c}\text { Avg } \\
\text { emergence }\end{array}$ \\
\hline & & \multicolumn{2}{|c|}{$(\mathrm{DAP}, \%)$} & \multicolumn{2}{|c|}{$(\mathrm{DAP}, \%)$} & \multicolumn{2}{|c|}{$(\mathrm{DAP}, \%)$} \\
\hline \multirow{4}{*}{$\begin{array}{l}\text { Kentucky } \\
\text { bluegrass }\end{array}$} & Smart Seed - Penkoted $\AA$ & 10.8 & 41.0 & 12.5 & 76.0 & 9.0 & 76.0 \\
\hline & Smart Seed - no coating & 11.9 & 55.0 & 14.0 & 81.2 & 8.3 & 80.0 \\
\hline & Turfbuilder - heavy Zeba ${ }^{\circledR}$ & 13.2 & 58.0 & 13.0 & 90.0 & 9.0 & 75.0 \\
\hline & $\operatorname{LSD}(0.05)^{\mathrm{y}}$ & 3.5 & NS & 1.5 & 8.5 & NS & 10.8 \\
\hline \multirow[t]{4}{*}{ Tall fescue } & Smart Seed - Penkoted $®$ & 6.7 & 74.0 & 8.3 & 93.0 & 12.0 & 92.0 \\
\hline & Smart Seed - no coating & 7.0 & 44.0 & 8.0 & 95.0 & 12.8 & 94.0 \\
\hline & Turfbuilder - heavy Zeba ${ }^{\circledR}$ & 6.8 & 75.0 & 8.8 & 95.0 & 13.0 & 88.0 \\
\hline & Turfbuilder - partial Zeba ${ }^{\circledR}$ & 6.3 & 58.0 & 8.5 & 94.0 & 12.0 & 89.0 \\
\hline
\end{tabular}

${ }^{2}$ Penkoted ${ }^{\circledR}$ (Pennington Seed, Madison, GA), Zeba ${ }^{\circledR}$ (Zeba, Beaverton, OR).

y Least significant difference $(P=0.05)$ can be used to compare means within a soil type and turfgrass species; Ns = not significant.

more of an impact in these soil types than in heavier soils where nutrients and water would be more readily available. Although the coatings improved the speed of kentucky bluegrass germination in the sandy loam soil, the overall emergence was unaffected by the Penkoted ${ }^{\circledR}$ or Zeba ${ }^{\circledR}$ coating. In the Woodburn silt loam soil, coating had a significant effect on kentucky bluegrass emergence percentage, but there were no significant differences when comparing the Penkoted $\AA$ or Zeba ${ }^{\circledR}$ coating to their uncoated control (Table 2).

Overall, the results of these studies support earlier trials (Berdahl and Barker, 1980; Bruneau et al., 1989; Dowling, 1978; Hathcock et al., 1984a; Hathcock et al., 1984b) and suggest that seed coatings have a minimal effect on speed of emergence or overall emergence of turfgrass seeds, and, in some situations, have a negative effect. In the present trial, larger seeds such as tall fescue were less affected by coatings than smaller-seed species such as kentucky bluegrass (Table 2). Because kentucky bluegrass has historically been described as having slow germination and poor seedling vigor, one would expect a greater effect of seed coatings, although the effects were inconsistent across soil types and seed types (Table 2 ). In addition, it appears that seed coatings had a positive effect on germination and emergence only in sandier soils, suggesting that they may be beneficial only in conditions where water and nutrients are limiting.

\section{Literature cited}

Berdahl, J.D. and R.E. Barker. 1980. Germination and emergence of Russian wildrye seeds coated with hydrophilic materials. Agron. J. 72:1006-1008.

Bishnoi, U.R. and J. Wilhite. 2005. Germination and stand establishment of polymer coated canola (Brassica napus L.) seeds subjected to moisture stress and various planting depths and soils. Seed Technol. 27:161-166.

Bruneau, A.H., C.H. Peacock, and J.M. DiPaola. 1989. Cool season turfgrass establishment with fertilizer coated seed. Intl. Turf. Res. Conf. 6:263-265.

Dowling, P.M. 1978. Effect of seed coatings on the germination, establishment, and survival of oversown pasture species at Glen Innes, New South Wales. N.Z. J. Expt. Agr. 2:161-166.

Hathcock, A.L., P.H. Dernoeden, J.J. Murray, and D.J. Wehner. 1984a. Seed germination of tall fescue and kentucky bluegrass as affected by adhesives. HortScience 19:442-443.

Hathcock, A.L., P.H. Dernoeden, T.R. Turner, and M.S. McIntosh. 1984b. Tall fescue and kentucky bluegrass response to fertilizer and lime seed coatings. Agron. J. 76:879-883.

Nault, B.A., R.W. Straub, and A.G. Taylor. 2006. Performance of novel insecticide seed treatments for managing onion maggot (Diptera: Anthomyiidae) in onion fields. Crop Prot. 25:58-65.

Otey, F.H. 1983. Starch-based products for agriculture. Proc. Natl. Agr. Plastics Cong. 17:12-15.

Peltonen-Sainio, P., M. Kontturi, and J. Peltonen. 2006. Phosphorus seed coating enhancement on early growth and yield components in oat. Agron. J. 98:206211.

Rice, W.A., G.W. Clayton, N.Z. Lupwayi, and P.E. Olsen. 2001. Evaluation of coated seeds as a rhizobium delivery system for field pea. Can. J. Plant Sci. 81: 247-253.

Salter, W.J. and J.M. Smith. 1986. Peas: Control of establishment pests and diseases using metalaxyl based seed coatings. Asp. Appl. Biol. 12:135-148.

Scott, D. and R.J.M. Hay. 1974. Some physical and nutritional effects of seed coating. Sectional Papers Intl. Grass. Congr. p. 316-324.

Woodhouse, J.M. and M.S. Johnson. 1991. The effect of gel-forming polymers on seed germination and establishment. J. Arid Environ. 20:375-380. 